Article

\title{
Economic Impacts of Climate Change on Cereal Production: Implications for Sustainable Agriculture in Northern Ghana
}

\author{
Anslem Bawayelaazaa Nyuor ${ }^{1, *}$, Emmanuel Donkor ${ }^{2, *}$, Robert Aidoo ${ }^{3}$, Samuel Saaka Buah ${ }^{1}$, \\ Jesse B. Naab ${ }^{1}$, Stephen K. Nutsugah ${ }^{1}$, Jules Bayala ${ }^{4}$ and Robert Zougmoré ${ }^{5}$ \\ 1 CSIR-Savanna Agricultural Research Institute (CSIR-SARI), P.O. Box TL 52, Tamale, Ghana; \\ ssbuah@yahoo.com (S.S.B.); jessenaab@gmail.com (J.B.N.); sknutsugah@hotmail.com (S.K.N.) \\ 2 Department of Food Business and Development, University College Cork, T12 YN60 Cork, Ireland \\ 3 Department of Agricultural Economics, Agribusiness \& Extension, Kwame Nkrumah University of Science \\ and Technology, Kumasi, Ghana; badubob@yahoo.co.uk \\ 4 ICRAF-WCA Sahel Node, BP E5118 Bamako, Mali; j.bayala@cgiar.org \\ 5 CCAFS-West Africa Program, ICRISAT WCA-Mali, BP 320 Bamako, Mali; r.zougmore@cgiar.org \\ * Correspondence: ansnyuor@yahoo.com (A.B.N.); emmanuel.donkor@ucc.ie (E.D.); \\ Tel.: +223-20-70-92-20 (A.B.N.); +353-89-98-72-588 (E.D.)
}

Academic Editors: Michael A. Fullen and Marc A. Rosen Received: 27 December 2015; Accepted: 25 July 2016; Published: 3 August 2016

\begin{abstract}
This paper investigates the economic impacts of climate change on cereal crop production in Northern Ghana using 240 households comprising maize and sorghum farmers. The Ricardian regression approach was used to examine the economic impacts of climate change based on data generated from a survey conducted in the 2013/2014 farming seasons. Forty-year time-series data of rainfall and temperature from 1974 to 2013, together with cross-sectional data, were used for the empirical analysis. The Ricardian regression estimates for both maize and sorghum showed varying degrees of climate change impacts on net revenues. The results indicated that early season precipitation was beneficial for sorghum, but harmful for maize. However, mid-season precipitation tended to promote maize production. Temperature levels for all seasons impacted negatively on net revenue for both crops, except during the mid-season, when temperature exerted a positive effect on net revenue for sorghum. Our findings suggest that appropriate adaptation strategies should be promoted to reduce the negative impacts of prevailing climate change on cereal crop production.
\end{abstract}

Keywords: economic impact; climate change; cereal; Ricardian approach; sustainability

\section{Introduction}

Northern Ghana accounts for over $40 \%$ of agricultural land in Ghana and is considered to be the breadbasket of the country [1]. Agricultural production in Ghana depends largely on rainfall. Irrigation accounts for only $0.2 \%$ of total cultivable land [2]. Therefore, climate is one of the main determinants of agricultural production. The trend of climatic variables, such as rainfall and temperature, is described as irregular in Northern Ghana. This pattern has serious economic impacts on agriculture, particularly in semi-arid regions [3].

The agricultural sector in the country has the potential to grow by as much as $6 \%$ per annum [4]. However, the sector is bedeviled by many problems. One of the problems is low soil fertility as a result of continuous cultivation on the same piece of land. Farmers also face the challenge of inadequate access to productive inputs and credit, and inefficient input and output marketing systems. Another important constraint to crop production in Ghana, and Northern Ghana in particular, is climate change. Agriculture in the north is rain-fed, characterized by variable climatic conditions, resulting from the 
observed changes in climate. Northern Ghana experiences a unimodal rainfall regime. Irrigation facilities are inadequate in most areas of Northern Ghana, especially for cereal production. The unpredictable rainfall pattern disrupts farmers' decision-making processes. The effects have two dimensions - on the one hand, the farming seasons are punctuated by mid-season drought and, on the other hand, excessive rains are experienced, causing heavy flooding. For example, the higher concentration of rainfall has increased the frequency and severity of floods in Northern Ghana over the last two decades $[5,6]$. The changing patterns of climatic variables, such as rainfall and temperature, may force farmers to change their crop choice in order to adapt to or cope with such changes in climatic conditions. The choice of crops influences farm income. The inability of farmers to predict current planting time could also affect yield and income. The obvious relationship between climate change and farm net revenue is the direct effect of climatic factors such as rainfall and temperature on agriculture, which is the main revenue source for smallholder farmers.

Agriculture forms the backbone of the Ghanaian economy, but is dependent on climate. Unfortunately, the phenomenon of climate change has only recently become a central part of agricultural policy discussions in the country [7].

There is much literature on the implications of prevailing climate change for food production globally [8-12]. Similarly, in Africa, studies have considered the economic impacts of climate change on the rural economy, particularly on agriculture [12-17]. Although some studies have been carried out in Ghana, most of these do not explicitly estimate the economic implications of climate change on cereal production $[7,18-21]$. This current study therefore bridges this knowledge gap by rigorously examining the economic impacts of key climate variables (rainfall and temperature) on cereal crop production in rural Northern Ghana using the Ricardian model. The model examines the effects of climate variables, soil characteristics, and institutional and socio-economic factors on net farm income.

The study provides useful findings based on the peculiarities of different districts in Northern Ghana. This allows for effective targeting of policies or strategies to specific districts depending on their particular conditions. It is an interdisciplinary study, taking into account biophysical and socio-economic variables aimed at facilitating channels from science to policy that are crucial to mitigate land degradation and foster development [22]. The effects of changing rainfall and temperature patterns on cereal crop production in specific districts in Northern Ghana have not been evaluated empirically to date to inform policy and investment decisions. Therefore, the main objective of this study was to investigate the economic impacts of changes in key climatic variables on cereal crop production in selected districts in Northern Ghana. The research methodology employed to address the main objective is presented in Section 2. Section 3 provides the key findings of the study, while Section 4 presents the discussion of the econometric results and Section 5 presents the conclusions and formulates policy recommendations based on the key findings.

\section{Materials and Methods}

\subsection{Analytical Framework}

The Ricardian approach is an econometric estimation procedure for assessing the economic impact of climate change on agricultural production. It is an empirical approach developed by Mendelsohn et al. [23] to measure the value of climate in the USA. The model analyzes a cross-section of farms across different climatic conditions, and examines the relationship between the value of land or net revenue and agro-climatic factors [24,25]. In their study, Mendelsohn et al. [23] used both net revenue and land value to measure climate change impacts. Other studies use only land values. For instance, Polsky and Esterling [25] used only land value as the dependent variable in their study to estimate the impact of climate change on US agriculture.

Under this approach, land rent is seen as the net revenue from the best use of the land. It is assumed to reflect the net productivity of farmland. Consequently, farm value (V) reflects the present value of future net productivity. The Ricardian model's specification is based on a set of 
well-behaved (twice continuously differentiable and strictly quasi-concave with positive marginal products) production functions of the form [25]:

$$
Q_{i}=Q_{i}\left(K_{i}, E_{i}\right)
$$

where $Q_{i}$ is the quantity of agricultural commodity produced, and $K_{i}$ is a vector of factor inputs $j$ used to produce $Q_{i}$. $E_{i}$ defines a vector of exogenous environmental factors, such as temperature, precipitation and soil, characterizing the production sites. Given a set of factor prices, $W_{i}, E_{i}$ and $Q_{i}$, cost minimization gives the cost function:

$$
C_{i}=C_{i}\left(Q_{i}, W_{i}, E_{i}\right)
$$

where $C_{i}$ is the cost of production and $W_{i}\left(w_{1}, w_{2}, \ldots, w_{n}\right)$ is the vector of factor prices. Using the cost function, $C_{i}$, at given market prices, profit maximization by farmers on a given site can be specified as:

$$
\operatorname{Max} \Pi=\left[P_{i} Q_{i}-C_{i}\left(Q_{i}, W, E\right)-P_{L} L_{i}\right]
$$

where $P_{L}$ is the annual cost or rent of land at that site, such that under perfect competition all profits in excess of normal returns to all factors (rents) are equal to zero.

$$
P_{i} Q_{i}{ }^{*}-C_{i}{ }^{*}=\left(Q_{i}{ }^{*}, W_{i}, E_{i}\right)-P_{L} L_{i}=0
$$

If the production of good $i$, is the best use of the land given $E$, the observed market rent for the land will be equal to the annual net profits from the production of the good. Solving for $P_{L}$ from the above equation gives land rent per hectare to be equal to net revenue per hectare.

$$
P_{L}=\left(P_{i} Q_{i}{ }^{*}-C_{i}\left(Q_{i}{ }^{*}, W, E\right)\right) / L_{i}
$$

The present value of the stream of current and future revenues gives the land value $V_{L}$ :

$$
V_{L}=\int_{0}^{\infty} P_{L} e^{-r t} d t=\int_{0}^{\infty}\left[P_{i} Q_{i}{ }^{*}-C_{i}\left(Q_{i}{ }^{*}, W, E\right) / L_{i}\right] e^{-r t} d t
$$

The issue to be analyzed is the impact of exogenous changes in environmental variables on net economic welfare $(\Delta W)$. The net economic welfare is the change in welfare induced or caused by the changing environment from a given state to another. Economic welfare change is measured in terms of change in the capitalized value of land or, alternatively, in net farm income [23]. Consider an environmental change from the environmental state $A$ to $B$, which causes environmental inputs to change from $E_{\mathrm{A}}$ to $E_{B}$. The change in annual welfare from this environmental change, is given by:

$$
\begin{gathered}
\Delta W=W\left(E_{B}\right)-W\left(E_{A}\right)=\int_{0}^{Q_{B}}\left[\left(P_{i} Q_{i}-C_{i}\left(Q_{i}, W, E_{B}\right) / L_{i}\right] e^{-r t} d Q\right. \\
-\int_{0}^{Q_{A}}\left[\left(P_{i} Q_{i}-C_{i}\left(Q_{i}, W, E_{A}\right) / L_{i}\right] e^{-r t} d Q\right.
\end{gathered}
$$

Assuming that the market prices remain unchanged as a result of the change in $E$, then the above Equation (7) can be reduced to:

$$
\Delta W=W\left(E_{B}\right)-W\left(E_{A}\right)=\left[P Q_{B}-\sum_{i=1}^{n} C_{i}\left(Q_{i}, W, E_{B}\right)\right]-\left[P Q_{A}-\sum_{i=1}^{n} C_{i}\left(Q_{i}, W, E_{A}\right)\right]
$$


From Equation (5),

$$
P_{L} L=P_{i} Q_{i}^{*}-C_{i}\left(Q_{i}^{*}, W, E\right)
$$

Substituting Equation (9) into Equation (8) gives:

$$
\Delta W=W\left(E_{B}\right)-W\left(E_{A}\right)=\sum_{i=1}^{n}\left(P_{L B} L_{B i}-P_{L A} L_{A i}\right)
$$

where $P_{L A}$ and $L_{A}$ are at $E_{A}$ and $P_{L B}$ and $L_{B}$ are at $E_{B}$.

The present value of the welfare change is represented as:

$$
\int_{0}^{Q_{B}} \Delta W e^{-r t} d t=\sum_{i=1}^{n}\left(V_{L B} L B_{B i}-V_{L A} L_{A i}\right)
$$

The Ricardian model takes either Equation (10) or Equation (11), depending on whether data are available on annual net revenues or capitalized net revenues (land values $V_{L}$ ). The model in Equation (10) is employed for this study, as data on land prices for the selected districts are unavailable. This is the same approach followed by both Sanghi et al. [24] and Kumar and Parikh [26] in India.

The Ricardian method assumes that each farmer will seek to maximize net farm revenues by choosing inputs $(X)$ subject to climate, soils and economic factors. The resulting net revenue function observes the loci of maximum profits subject to the above factors. The model is a reduced-form hedonic price model of the observed loci of profits. The standard empirical Ricardian model relies on a quadratic formulation of climatic variables, as:

$$
\begin{gathered}
R_{i j}=\varpi_{0 j}+\sum_{j=1}^{2} \varpi_{j} E n v_{i j}+\sum_{j=3}^{4} \varpi_{j} E n v_{i j}^{2}+\sum_{j=1}^{J} \varphi_{j} \operatorname{Soil}_{i j}+\sum_{j=1}^{J} \delta_{j} \text { Socio }_{i j}+\sum_{j=1}^{J} \lambda_{j} I n s t_{i j}+u_{i j} \\
i=1,2, \ldots, N ; j=1 \text { (maize) }, 2(\text { sorghum })
\end{gathered}
$$

where $R_{i j}$ is net revenue per ha, $E n v_{i j}$ denotes a vector of climate variables including temperature and precipitation, Soil $i_{i j}$ represents a vector of soil characteristics, and Socio $i_{i j}$ and Inst $t_{i j}$ are vectors of household socio-economic and institutional factors related to the farmers. $\varpi_{0}, \varpi_{j}, \varphi_{j}, \delta_{j}, \lambda_{j}$ indicate the parameters to be estimated, while $u_{i j}$ is the error term. To capture the non-linear relationship between net farm revenues and climate variables, the estimation includes both the linear and quadratic terms of climate variables, $E n v_{i j}^{2}$ (temperature and precipitation).

One basic assumption of the Ricardian approach is that farmers would usually make adaptations that are profitable; hence, the method automatically captures the adaptation inherent in the market [23]. This makes the approach distinct from other approaches that do not take adaptation into account [27]. However, several criticisms have been put forward about the Ricardian approach over the years since it was developed. One of the major criticisms is about the role of price changes [28]. However, Reilly et al. [29] observed that considering the possibility that local supply might be dramatic, prices of food crops tend to be determined by world markets. Once crop production can be expanded in some parts of the world and contracted in others, any changes in the price of crops from global warming are expected to be minimal.

\subsection{Empirical Specification}

This study adopted the empirical models formulated by Mendelsohn and Dinar [30] and Ouedraogo et al. [15], while taking into account the climatic conditions of Northern Ghana. The basic concept of the models is to examine how long-term farm profitability varies with climatic factors (precipitation and temperature) and soil factors, while controlling for other factors. In addition, some 
important socio-economic and institutional factors are incorporated into the model. The empirical model is specified as:

$$
\begin{aligned}
& \text { Netrevenue }_{i k}=\varpi_{0 k}+\varpi_{1 k} E S P_{i k}+\varpi_{2 k} M S P_{i k}+\varpi_{3 k} L S P_{i k}+\varpi_{4 k} E S T_{i k}+\varpi_{5 k} M S T_{i k}+\varpi_{6 k} L S T_{i k} \\
& +\varpi_{7 k} E S P_{i k}^{2}+\varpi_{8 k} M S P_{i k}^{2}+\varpi_{9 k} L S P_{i k}^{2}+\varpi_{10 k} E S T_{i k}^{2}+\varpi_{11 k} M S T_{i k}^{2}+\varpi_{12 k} L S T_{i k}^{2}+\varpi_{13 k} L_{o a m y} \\
& +\varpi_{14 k} \text { SoilFert }_{i k}+\varpi_{15 k} \text { Education }_{i k}+\varpi_{16 k} \text { Householdz }_{i k}+\varpi_{17 k} \text { Farmsize }_{i k} \\
& +\varpi_{18 k} \text { Seeding }_{i k}+\varpi_{19 k} \text { Market }_{i k}+\varpi_{20 k} \text { Credit }_{i k}+\varpi_{21 k} \text { Extension }_{i k}+\varepsilon_{i k} \\
& k=1 \text { (Maize), } 2 \text { (Sorghum) }
\end{aligned}
$$

Netrevenue $_{i k}$ is the total net revenue (GH $\not$ ) per ha of cropland. ESP, MSP and LSP represent the amount of precipitation $(\mathrm{mm})$ during the early, mid and late seasons, respectively. EST, MST and LST denote the temperature levels $\left({ }^{\circ} \mathrm{C}\right)$ during the early, mid and late seasons, respectively. Loamy is assigned the value 1 if farmers' soil is loamy, and 0 if otherwise. SoilFert equals 1 if the farmer perceives soil to be fertile, and 0 if otherwise. Education indicates the number of years of formal schooling. Householdz is the number of people in the household, and Farmsize denotes the total farm area in hectares. Seeding rate refers to the quantity $(\mathrm{kg})$ of seed sown. Market is the distance from the house to the nearest market $(\mathrm{km})$. Credit equals 1 if the farmer has access to credit and 0 if otherwise. Extension is the number of times the farmer has contact with the extension agent during the cropping season. $\varpi_{0}$ is the constant term, while $\varpi_{1}, \ldots, \varpi_{21}$ are the coefficients. $\varepsilon_{i}$ is the error term.

Based on the practical approach of this study, both qualitative and quantitative data were considered paramount. Our focus was on establishing some relationship between farmer perception of soil variables and net revenue, particularly where these perceptions do not reflect the real soil conditions of farmers' fields. It is important, however, to recognize the qualitative assessment of the fertility status of farmers' fields, based on their long-standing experience of crop production. These qualitative soil variables were included to investigate to what extent they would influence net revenue. It is important to emphasize that establishing the real soil conditions of farmers' fields has always been very difficult, because most farmers do not carry out analyses of their soils due to poverty and lack of information. Instead, farmers rely on the perception they have about their soil conditions, mostly based on visual observation of color and trends in crop yield over time. Although it is difficult to match these attributes to real laboratory test results, understanding farmers' perceptions of their soil conditions is crucial for effective policy formulation. Their perception may trigger the need for policymakers to make policies aimed at improving soil conditions. Based on the assumption that the Ricardian approach inherently captures adaptation options, the study sought information about farmers' perceptions of, and adaptation strategies to climate change currently practiced by the farmers. These practices are expected to influence the estimated results from the Ricardian models.

Descriptive statistics, such as mean, standard deviation and frequency distribution tables, were used to describe the data. In addition to the Ricardian models, non-parametric statistical tests, such as Mann-Kendall, were used to determine the historical trend and presence of statistical significance in hydrologic climatic variables, such as precipitation and temperature, with reference to changes in climatic conditions [31]. Stata version 12 was used to analyze the descriptive statistics, Ricardian models and the non-parametric test (Mann-Kendall).

\subsection{Source and Data Description}

The study employed a multistage random sampling technique to select respondents. Three regions in Northern Ghana (Northern, Upper East and Upper West) were purposively selected in the first stage. In the second stage, two districts were randomly selected from each region, making six districts in total. The districts were Sanerigu and Bole (Northern), Bawku Municipality and Kassena Nankana East District (Upper East) and Jirapa and Sissala East Districts (Upper West). The third stage involved random selection of two communities within a $15 \mathrm{~km}$ radius of the meteorological station, done through balloting. This was done to minimize the variations in rainfall distribution within the 
selected areas in the district. In each community, 20 farmers producing maize/sorghum were selected randomly. In total, 240 maize/sorghum farmers were used for the study. Survey data on production and socio-economic attributes were collected during the 2013/2014 cropping season. The study relied on monthly precipitation and temperature data collected from the Ghana Meteorological Agency from its weather stations across the six selected districts in Northern Ghana. Forty-year time series data, from 1974 to 2013, were considered to reflect long-term climate changes rather than short-term variations. The study also sought information about farmers' perceptions of climate change and the adaptation strategies currently being practiced by the farmers. These practices need to be investigated to establish how they relate to the estimated results of the Ricardian models.

Table 1 presents descriptive statistics of the socio-economic and climatic variables. The mean net revenue recorded for maize and sorghum were Ghф 2266.38 (US\$ 600.37) and Ghф 493.33 (US\$130.68) per ha, respectively. Temperatures in the north are generally high all year round. Temperatures during the effective growing season of crops range from a mean of $36.9^{\circ} \mathrm{C}$ in the early season to $33.5^{\circ} \mathrm{C}$ in the late season. The monthly rainfall during the effective growing season ranges from $68.03 \mathrm{~mm}$ in the early season to $93.70 \mathrm{~mm}$ in the late season, with the mid-season period recording the highest mean rainfall.

Soil fertility status has serious implications for farm productivity and profitability. The study sought to assess farmers' perceptions of the fertility status of their soil, as well as the soil texture on which they cultivate maize and sorghum. Soil texture has been used as a proxy to determine the nutrient and moisture availability. Soil characteristics play critical roles in plant growth. The survey data show that $45 \%$ of maize farmers perceived their soil as having a loamy texture, while $37 \%$ of sorghum farmers had a similar perception of their soil texture. Similar subjective observations were made about soil fertility. Forty-four percent of the respondents representing maize farmers reported their soils as fertile, while this figure was $47 \%$ for sorghum farmers.

The household socio-economic characteristics of the respondents are presented in respect of both crops (Table 1). The survey data show that the mean number of years a farmer had spent in school was 2.68 and 2.13 years for maize- and sorghum-farming household heads, respectively. A larger proportion of the farming population in Northern Ghana is unable to read and write. This could affect the adoption of modern agricultural innovations, since the farmers may not be enlightened enough to appreciate the benefits of such innovations (Table 1).

The mean number of people in a household was 10.40 people in maize-farming households, whereas the amount was 10.47 people for sorghum-farming households. The size of a household has a direct relationship with agricultural output, because the main source of labor in most farming households in Northern Ghana comes from the household. The number of productive people in farming households could determine farm size and hence output. Timely execution of farm operations could be much easier in a household with active individuals. Farmers practiced mixed cropping farming systems in Northern Ghana, resulting in a small size of land allocated to various crops due to limited arable land in some areas, especially in the Upper East and West regions. The farmers cultivated a mean of 2.71 and 2.99 ha of land under maize and sorghum, respectively.

Achieving maximum crop yield depends partly on the quantity of seed planted per area. The actual plant population is achieved with the right quantity of seed planted, giving rise to the desired yield. The mean quantity of maize seed used per ha was $22.91 \mathrm{~kg}$, and it was $3.23 \mathrm{~kg}$ in the case of sorghum. 
Table 1. Descriptive statistics of production, climatic, institutional and socio-demographic variables.

\begin{tabular}{|c|c|c|c|c|c|c|c|}
\hline \multirow{2}{*}{ Variable } & \multirow{2}{*}{ Description } & \multicolumn{3}{|c|}{ Maize } & \multicolumn{3}{|c|}{ Sorghum } \\
\hline & & $n$ & Mean & SD & $n$ & Mean & SD \\
\hline \multicolumn{8}{|c|}{ Crop output/Revenue } \\
\hline OUTPUT & Output by crop (kg) & 120 & 2327.38 & 38.82 & 120 & 1213.55 & 13.48 \\
\hline NETRV & Net revenue by crop (GHф) & 120 & 2266.38 & 1643.83 & 120 & 493.33 & 139.61 \\
\hline \multicolumn{8}{|c|}{ Meteorological variables } \\
\hline ESP & Early season precipitation (mm) & 120 & 68.03 & 1.55 & 120 & 68.03 & 1.55 \\
\hline MSP & Mid-season precipitation (mm) & 120 & 181.65 & 1.70 & 120 & 181.65 & 1.70 \\
\hline LSP & Late season precipitation (mm) & 120 & 93.70 & 1.41 & 120 & 93.70 & 1.41 \\
\hline EST & Early season temperature $\left({ }^{\circ} \mathrm{C}\right)$ & 120 & 36.90 & 0.12 & 120 & 36.90 & 0.12 \\
\hline MST & Mid-season temperature $\left({ }^{\circ} \mathrm{C}\right)$ & 120 & 31.15 & 0.08 & 120 & 31.15 & 0.08 \\
\hline LST & Late season temperature $\left({ }^{\circ} \mathrm{C}\right)$ & 120 & 33.56 & 0.08 & 120 & 33.56 & 0.08 \\
\hline \multicolumn{8}{|c|}{ Soil characteristics } \\
\hline Loamy & $\begin{array}{l}1 \text { if soil is loamy texture } \\
\text { and } 0 \text { otherwise }\end{array}$ & 120 & 0.45 & 0.49 & 120 & 0.37 & 0.48 \\
\hline Soilfert & $\begin{array}{l}1 \text { if farmer perceives the soil to be } \\
\text { fertile and } 0 \text { otherwise }\end{array}$ & 120 & 0.44 & 0.49 & 120 & 0.47 & 0.50 \\
\hline \multicolumn{8}{|c|}{ Household characteristics } \\
\hline Educ & $\begin{array}{l}\text { Number of years of } \\
\text { formal schooling }\end{array}$ & 120 & 2.68 & 4.62 & 120 & 2.31 & 4.10 \\
\hline Hsize & $\begin{array}{l}\text { Number of people who live and } \\
\text { eat from the same household }\end{array}$ & 120 & 10.40 & 5.43 & 120 & 10.47 & 5.19 \\
\hline Farm size & Total cultivated land (ha) & 120 & 2.712 & 2.52 & 120 & 2.99 & 6.54 \\
\hline Seeding & Quantity of seed planted (kg/ha) & 120 & 22.91 & 42.32 & 120 & 3.23 & 2.33 \\
\hline \multicolumn{8}{|c|}{ Institutional factors } \\
\hline Market & $\begin{array}{l}\text { Distance from house to the nearest } \\
\text { input and output market }(\mathrm{Km})\end{array}$ & 120 & 8.69 & 9.69 & 120 & 7.29 & 8.58 \\
\hline Credit & $\begin{array}{c}1 \text { if farmer has access to credit } \\
\text { and } 0 \text { otherwise }\end{array}$ & 120 & 0.12 & 0.32 & 120 & 0.08 & 0.28 \\
\hline Extension & $\begin{array}{l}\text { Number of times farmers have } \\
\text { contact with extension } \\
\text { agents per season }\end{array}$ & 120 & 4.18 & 6.15 & 120 & 4.40 & 5.80 \\
\hline
\end{tabular}

Institutional factors play crucial roles in the day-to-day operation of farm businesses. Some of these factors considered in this study include access to formal credit, formal agricultural extension services, and distance to input markets. Financial credit is an essential factor in easing farmers' financial burden. It helps them in acquiring basic agricultural inputs, such as labor, fertilizers, seed and herbicides. Access to credit by farmers, however, seemed to be a limiting factor in the selected districts as only $12 \%$ and $8 \%$ of respondents could access credit in respect of maize and sorghum, respectively. Financial constraints, among other factors, are disincentives to carrying out farm operations and acquiring farm inputs (both fixed and variable).

Agricultural extension service delivery could be an important tool for educating rural farmers in modern agricultural innovations and other important issues, such as the negative effects of climate change on livelihoods. Farmers need basic farming information in order to improve their farming. Information dissemination has been the responsibility of the Ministry of Food and Agriculture (MoFA), Non-governmental organizations (NGOs) and, to some extent, farmers sharing their own experiences. From the survey results, maize farmers reported that they received formal agricultural extension contact 4.18 times during the 2014 cropping season. The frequency of extension visit to sorghum farmers was slightly different with a mean of 4.40 times reported during the same season as maize.

The presence of a market in a district or community serves as an avenue for economic activities. Markets serve as points for the purchase of farm inputs and sale of farm produce at the end of the planting season. Distance to the nearest input market could have direct implications on productivity. Travelling long distances to access input market could be a hindrance to farming and commercial 
activities in Northern Ghana. This is because farmers would have to spend their productive time in travelling to nearby towns in search for farm inputs. Transport facilities (vehicles) are limited coupled with the deplorable nature of roads in the study area. Maize and sorghum farmers travel a mean distance of 8.69 and $7.29 \mathrm{~km}$ to the nearest market, respectively.

\section{Results}

\subsection{Trend Analysis of Climatic Variables}

Table 2 provides a non-parametric analysis of rainfall and temperature to detect the existence of any trends in these variables. It is evident from the results that there is a significant positive trend in temperature over the period. Both variables exhibited positive trends, even though that of rainfall was not statistically significant. The Mann-Kendall test, a non-parametric approach, ascertains the significance of time series variables, such as rainfall and temperature. One of the test conditions is that, if the p-value is less than the significance level $\alpha$ (alpha) $=0.05, \mathrm{H}_{0}$ is rejected. Rejecting $\mathrm{H}_{0}$ indicates that there is a trend in the time series, while accepting $\mathrm{H}_{0}$ suggests no trend. The results indicate that the null hypothesis was rejected in the case of temperature in all the selected districts in Northern Ghana. The opposite is the case for rainfall. This implies that there has been a significant change in average temperature patterns/trends over the past 40 years in the studied areas.

Table 2. Non-parametric analysis of rainfall and temperature.

\begin{tabular}{ccccc}
\hline District & Mann-Kendall & Kendall's Tau & $\boldsymbol{p}$-Value (2-Tail) & Decision \\
\hline \multicolumn{5}{c}{ Precipitation } \\
\hline Sanerigu & 4.00 & 0.005 & 0.972 & Do not reject $\mathrm{H}_{0}$ \\
Bole & 80.00 & 0.103 & 0.357 & Do not reject $\mathrm{H}_{0}$ \\
Bawku & 50.00 & 0.103 & 0.972 & Do not reject $\mathrm{H}_{0}$ \\
Navrongo & 50.00 & 0.064 & 0.568 & Do not reject $\mathrm{H}_{0}$ \\
Babile & 8.00 & 0.010 & 0.935 & Do not reject $\mathrm{H}_{0}$ \\
Tumu & 38.00 & 0.049 & 0.666 & Do not reject $\mathrm{H}_{0}$ \\
\hline & Temperature & \\
\hline Sanerigu & 308.00 & 0.410 & $<0.001$ & Reject $\mathrm{H}_{0}$ \\
Bole & 447.00 & 0590 & $<0.001$ & Reject $\mathrm{H}_{0}$ \\
Bawku & 225.00 & 0.298 & $<0.01$ & Reject $\mathrm{H}_{0}$ \\
Navrongo & 295.00 & 0.392 & $<0.001$ & Reject $\mathrm{H}_{0}$ \\
Babile & 317.00 & 0.416 & $<0.001$ & Reject $\mathrm{H}_{0}$ \\
Tumu & 500.00 & 0.654 & $<0.001$ & Reject $\mathrm{H}_{0}$ \\
\hline
\end{tabular}

\subsection{Econometric Analysis of the Ricardian Models}

To avoid violation of any classical assumption underlying multivariate regression models, some econometric tests were conducted. We conducted the Breusch-Pagan test to check for the presence of heteroscedasticity in the models. The test indicates that heteroscedasticity is present in both the maize and sorghum models. To address this, a robust estimation was employed to compute standard errors [32]. Other related problems with cross-sectional regression models are multicollinearity among explanatory variables, and the impact of outliers. These econometric issues would mostly influence the reliability of the results if not properly addressed. Multicollinearity was controlled by dropping the most problematic variables, after a correlation test was performed among the explanatory variables. For example, some socio-demographic variables, such as the age of the respondents, gender, marital status and farming experience of the household head, were all excluded from the models because they were highly correlated. The problem of multicollinearity is normally an issue of extent rather than absence and so cannot be eliminated completely [32]. Outliers in the net revenue data were also excluded from the estimation. 
The fitness of the models was ascertained using the $\mathrm{R}^{2}$ values. The $\mathrm{R}^{2}$ of 0.71 indicates that $71 \%$ of variations in the net revenue per hectare of maize were explained by the variations in the explanatory variables. Similarly, the $\mathrm{R}^{2}$ of 0.46 , representing $46 \%$ of variation in net revenue per hectare of sorghum, was explained by variations in the explanatory variables. The results indicate that both environmental and socio-economic factors account for the variations in net farm revenue (F-statistic $=5.66$ and 6.08 for maize and sorghum, respectively). The preliminary investigation of the climate variables showed that the mean precipitation levels for the early, mid and late seasons varied considerably (mean $=68.03 \mathrm{~mm}$, $\mathrm{SD}=1.55$ for early precipitation, mean $=181.65 \mathrm{~mm}, \mathrm{SD}=1.70$ for mid-season precipitation, and mean $=36.90 \mathrm{~mm}, \mathrm{SD}=0.12$ for late season precipitation). Mean temperatures equally varied across seasons $($ mean $=36.90, \mathrm{SD}=0.12$, mean $=31.15, \mathrm{SD}=33.56, \mathrm{SD}=0.08$ for early, mid and late season temperatures, respectively).

The multivariate regression estimates are presented in Table 3. The impacts of seasonal climate variables vary across the seasons and models (crops). Both linear and quadratic terms were significant in their effects in some seasons. Our results show that the impact of quadratic seasonal climate variables on crop net revenue was substantial, judging by their coefficients. However, our results indicate that, even though both linear and quadratic terms play a role, it is insufficient to determine such effects by the coefficients alone [14].

Table 3. Ricardian regression parameter estimates of net revenues (Ghф) per hectare.

\begin{tabular}{|c|c|c|c|c|c|}
\hline \multirow[b]{2}{*}{ Variable } & \multirow{2}{*}{ Parameter } & \multicolumn{2}{|c|}{ Maize Model } & \multicolumn{2}{|c|}{ Sorghum Model } \\
\hline & & Coefficient & $\begin{array}{c}\text { Robust } \\
\text { Standard Error }\end{array}$ & Coefficient & $\begin{array}{c}\text { Robust } \\
\text { Standard Error }\end{array}$ \\
\hline Constant & $\varpi_{0}$ & -266.40 & 277.900 & $-424.25^{* * *}$ & 119.390 \\
\hline \multicolumn{6}{|c|}{ Climate variables } \\
\hline ESP & $\varpi_{1}$ & $-530.10 *$ & 284.800 & $324.50 *$ & 175.800 \\
\hline MSP & $\varpi_{2}$ & $588.70 * *$ & 252.600 & -48.20 & 94.100 \\
\hline LSP & $\varpi_{3}$ & 3.60 & 13.600 & -52.90 & 64.100 \\
\hline EST & $\varpi_{4}$ & -423.40 & 164.700 & -635.30 & 456.60 \\
\hline MST & $\varpi_{5}$ & -156.60 & 603.400 & $420.80^{* *}$ & 176.600 \\
\hline LST & $\varpi_{6}$ & $-811.70^{* * *}$ & 252.600 & $-345.70 *$ & 187.600 \\
\hline $\mathrm{ESP}^{2}$ & $\varpi_{7}$ & 3.90 * & 1.900 & $-2.80 *$ & 1.500 \\
\hline $\mathrm{MSP}^{2}$ & $\varpi_{8}$ & $-1.40 *$ & 0.600 & 0.10 & 0.200 \\
\hline $\mathrm{LSP}^{2}$ & $\varpi_{9}$ & -0.10 & 0.700 & 0.40 & 0.400 \\
\hline $\mathrm{EST}^{2}$ & $\Phi_{10}$ & $-412.30 * * *$ & 102.000 & 82.70 & 189.800 \\
\hline $\mathrm{MST}^{2}$ & $\varpi_{11}$ & 340.50 & 715.100 & -657.90 & 280.700 \\
\hline $\mathrm{LST}^{2}$ & $\varpi_{12}$ & $-1193.80^{* * *}$ & 532.300 & $504.4 *$ & 278.500 \\
\hline \multicolumn{6}{|c|}{ Soil characteristics } \\
\hline Loamy & $\varpi_{13}$ & 456.10 * & 231.900 & 159.31 * & 74.270 \\
\hline SoilFert & $\varpi_{14}$ & $560.50 *$ & 268.800 & $166.40^{* *}$ & 71.900 \\
\hline \multicolumn{6}{|c|}{ Household characteristics } \\
\hline Education & $\varpi_{15}$ & $37.65^{* *}$ & 17.580 & -4.30 & 6.300 \\
\hline Householdz & $\varpi_{16}$ & $41.30 *$ & 23.400 & 13.70 & 8.100 \\
\hline Farmsize & $\varpi_{17}$ & $11.40^{* *}$ & 4.900 & $9.30^{* * *}$ & 3.100 \\
\hline Seeding & $\varpi_{18}$ & $18.50^{* * *}$ & 17.580 & 22.90 & 14.600 \\
\hline \multicolumn{6}{|c|}{ Institutional factors } \\
\hline Market & $\varpi_{19}$ & 4.78 & 16.980 & 8.40 & 7.800 \\
\hline Credit & $\varpi_{20}$ & 33.51 * & 16.480 & -100.25 & 104.120 \\
\hline Extension & $\Phi_{21}$ & $40.00^{* *}$ & 18.100 & -100.20 & 104.100 \\
\hline \multicolumn{6}{|c|}{ Diagnostic statistics } \\
\hline $\mathrm{R}^{2}$ & & 0.71 & & 0.46 & \\
\hline F-statistic & & $5.66^{* * *}$ & & $6.08^{* * *}$ & \\
\hline $\mathrm{n}$ & & 120 & & 120 & \\
\hline
\end{tabular}

* Significant at $p<0.01 ;{ }^{* *}$ significant at $p<0.05 ;{ }^{* * *}$ significant at $p<0.001$. Note US\$ $1=$ GhC 3.775 on 1 November 2015. 
The coefficients of early (spring), mid (summer) and late (fall) temperature, 423.4, 159.6 and 811.7, respectively, for maize, were found to significantly influence net revenue. Similarly, early and late season temperatures had a negative relationship with net revenue. However, we found that mid-season temperature had a positive effect on farm net revenue of sorghum per hectare. Additionally, the results indicated that mid-season precipitation was positively related to net revenue (coefficient $=558.7$ ) of maize producers, whereas early season precipitation had negative effects (with coefficient $=530.10$ ). The impact of early season precipitation was negative (coefficient $=324.50)$.

Table 3 further shows that soil variables significantly affected net revenue. For instance, the soil texture and soil perception variables for fertility had positive influences on net revenue for both crops. Seeding rate exerted significant positive impacts on the net revenue per hectare of maize farmers.

Household characteristics had significant influences on maize production. The results revealed that education, household size, farm size, credit and extension were positively correlated to net revenue from maize, whereas only farm size had a positive relationship with net revenue from sorghum.

\subsection{Climate Perception and Adaptation Strategies to Climate Change}

It is important to establish the relationship between farmers' perception of, and adaptation to, climate change and farm net revenue, since these practices are expected to influence the estimated results of the Ricardian approach.

Farmers interviewed in Northern Ghana indicated that they had observed some changes in the weather pattern over the past 20 years. An overwhelming majority (97.5\%) of farmers reported noticing some changes in the climate, whereas some $2.5 \%$ of farmers had not observed any change in climate over the reference period of 20 years. Farmer perceptions of climate change in Northern Ghana are presented in Table 4 . Most farmers (51.7\%) observed that mean precipitation had decreased. Some $41.6 \%$ observed an unpredictable pattern, $4.2 \%$ had not noticed any change, while a minority $(2.5 \%)$ indicated that precipitation had increased. Farmers' perceptions of a decrease in rainfall have direct implications for all cropping decisions, since crop production in Northern Ghana is mostly rain-fed. With regard to temperature, $76.7 \%$ of farmers believed that average temperature had increased. A minority $(10.8 \%)$ had witnessed an unpredictable temperature. Some $6.7 \%$ had not noticed any change in temperature, whereas $5.8 \%$ had witnessed a decrease in temperature (Table 4 ).

Table 4. Households' perceptions of climate change over the past 20 years in Northern Ghana.

\begin{tabular}{ccccc}
\hline \multirow{2}{*}{ Perceived Direction of Change } & \multicolumn{2}{c}{ Precipitation } & \multicolumn{2}{c}{ Temperature } \\
\cline { 2 - 5 } & $\boldsymbol{n}$ & $\mathbf{\%}$ & $\boldsymbol{n}$ & $\boldsymbol{\%}$ \\
\hline Increased & 120 & 2.50 & 120 & 76.70 \\
Decreased & 120 & 51.70 & 120 & 5.80 \\
No change & 120 & 4.20 & 120 & 6.70 \\
Unpredictable & 120 & 41.60 & 120 & 10.80 \\
\hline
\end{tabular}

Farmers' decision to adapt any climate-related strategy is often influenced by their perception of the effects of climate change and variability on crop production. This is evident in the responses of the farming households in Northern Ghana, where most (96.7\%) farmers indicated that they had adapted one practice/technology or the other aimed at minimizing the negative impact of climate change on crop production. However, their ability to adapt was affected by their lack of economic and technical resources, coupled with their vulnerability as a result of their overdependence on the weather. In contrast, farmers did not declare having knowledge constraints to manage their lands. This study identified seven adaptation strategies. Each of them is a bundle of several sub-strategies. Table 5 shows the bundles of adaptation options. Farmers were asked to identify the most practiced bundle to counteract the negative impact of climate change. 
Table 5. Adaptation strategies to climate change in Northern Ghana.

\begin{tabular}{ccc}
\hline Adaptation Strategy & Frequency & \% \\
\hline Crop management & 66 & 27.50 \\
Land management & 40 & 16.67 \\
Farm operation & 24 & 10.00 \\
Off-farm strategy & 14 & 5.83 \\
Livestock & 62 & 25.83 \\
Agro-forestry & 21 & 8.75 \\
Other strategies & 13 & 5.42 \\
\hline
\end{tabular}

It is important to recognize that some of these adaptation strategies are not entirely new; the change in their application from the past to now is that they are now considered as climate-smart practices. The study tried to understand practices that have been in existence and why they are considered as climate-related strategies by the farmers. Generally, it was found that there has been a renewed attitude towards their application as remedies aimed at increasing crop yield under the current changes in climatic conditions. In the past, the benefits of these practices were not well understood by farmers, for instance as measures to safeguard the farm environment against soil fertility loss. Some $27.5 \%$ of farmers reported the adoption of crop management strategies to minimize climate change effects on crop production. This bundle of strategies includes the use of local crop varieties, improved varieties, mixed cropping, crop rotation, diversification of crop varieties, and planting of early maturing varieties.

With respect to land management strategies, $16.67 \%$ of the households adopted practices such as the incorporation of crop residues into the soil, conservation agriculture, non-burning of crop residues, integrated soil fertility management, mulching, increased area of cultivated land, decreased area of cultivated land, inorganic fertilizer applications, and compost and manure applications as measures to minimize the effects of changes in climate variables on crop production.

Ten percent $(10 \%)$ of the farmers used farm operational strategies, such as changing the timing of farm operations (e.g., sowing, land preparation, adjusting amount and timing of inorganic fertilizer application) and good agricultural practices (e.g., planting in rows, integrated pest and disease management, use of tractor and bullock services).

Off-farm strategies, such as engaging in non-farm income-generating activities, membership of credit unions, and reducing daily intake of food, were also employed by farmers to mitigate the effects of climate change on their livelihoods. These strategies were implemented by just $5.83 \%$ of respondents.

Some $25.83 \%$ of households practiced livestock-related strategies, namely livestock production, livestock breed diversification and routine vaccination of livestock. Another climate change-mitigating strategy reported by farming households was agro-forestry. Although not widespread, $8.75 \%$ of farmers were engaged in agro-forestry. Practices such as tree planting, avoidance of indiscriminate felling of trees and participation in community tree plantation programs formed part of the agroforestry strategy.

Effective information dissemination on climate-related issues through appropriate communication channels is vital in broadening rural farmers' understanding of issues relating to climate change and adaptation. One of the major sources through which farmers obtain information in rural areas is the radio. Most farmers owned at least one radio. Radio is an important source of information, entertainment and, most importantly, education for most households in Northern Ghana. Civic education, and health and agricultural programs are usually aired in local dialects on both community and regional radio stations. It is common to find farmers tuning in to one radio station or the other to get agricultural and social information.

Finally, traditional and religious leaders have played leading roles in the fight against desertification and other practices that degrade the environment. As a commitment to confronting environmental challenges, community leaders and members sometimes undertake traditional and 
religious ceremonies, such as performing sacrifices and putting in place by-laws to reduce the negative impact of climate change on the environment.

\section{Discussion}

This study has provided empirical evidence to show that climate change has significant economic impacts on agriculture in Ghana, particularly for cereals. The impacts of seasonal climate variables vary across the seasons and models. Both linear and quadratic terms are significant in some seasons, which indicate that climate change has a non-linear impact on crop net revenues. The results show that the impact of quadratic seasonal climate variables on crop net revenue is not determined by the coefficients, but rather by their marginal effects [14].

The negative relationship between temperature and net revenue could be attributed to high temperatures across the entire growing season, especially during the early and late seasons, as depicted in Table 3. Increasing temperatures during the early and late seasons tend to reduce net revenue per hectare of sorghum by Gh $\phi 635.30$ (US\$168.29) and Gh $₫ 345.70$ (US\$ 91.58), respectively. This is quite substantial, given that the most recent (2014) per capita income of the country was US\$ 775.46 [1]. It is expected that, during the early season, a slightly higher temperature with an available level of moisture enhances germination, as this is the planting season. A higher temperature during the late season is beneficial for harvesting. It is important that by the time crops have completed their growth processes, a higher temperature later in the season quickly dries up the crops and facilitates harvesting. Our results corroborate those of Seo and Mendelsohn [10], who found that high temperatures and high precipitation in summer could reduce net revenue by US\$ 143.59 and US $\$ 39.91$ per hectare of rain-fed farms, respectively. For sorghum, mid-season temperature is positively related to net revenue, as a $1{ }^{\circ} \mathrm{C}$ rise in temperature during the mid-season (summer) increases the per hectare net revenue of sorghum producers by Gh $\not 20.80$ (US\$ 111.47). This finding, however, contradicts Deressa [16], who found that increasing temperatures during summer could reduce net revenue by US\$ 177.6, whereas a marginal increase in temperature during fall could increase net revenue by US\$1879.70. Additionally, mid-season and early season precipitation gave varying results in terms of magnitude and direction. The positive relationship between mid-season precipitation and net revenue implies that a $1 \mathrm{~mm}$ increase in precipitation in that season could increase maize revenue by Gh $\not 588.70$ (US\$ 155.95), but would results in a loss of Gh\&530.10 (US\$140.42) of net revenue in the early season. With the inadequate distribution of rain, increasing precipitation could be beneficial for crop maturation. Our finding is consistent with that of Esteve et al. [33], who indicate that climate change tends to reduce crop yield by $10 \%$. The reduction in net revenue of maize per hectare during early-season precipitation could be due to the usual delay in the onset of rains in recent times. This period is critical for germination and early crop development. Unlike maize, early season precipitation was beneficial for sorghum because of its ability to withstand harsher conditions compared to maize. Sorghum will benefit substantially from early season precipitation—by Gh $₫ 324.50$ (US\$ 85.96) of net revenue. Mid-season precipitation is equally crucial, as it is regarded as the period for cob and panicle initiation and development.

Although our results on soil perception variables have a positive relationship with net revenue for both crops, further studies on other soil characteristics would be necessary to reveal more information that would be relevant for farmers in Northern Ghana. This relationship may be explained by the fertility level and water-retention capacity of the soil as perceived by farmers, and may also serve as a proxy for the amount of organic content in the soil. The positive relationship between loamy soil and net revenue means that the value of this land is higher compared with other soil types. The dummy variable for soil fertility for both crops is positively correlated with net revenue. Even though it is hard to match farmer perceptions about their soil conditions with laboratory test results, farmers use some indicators, such as changes in crop yield (downward trend) and soil color compared with previous years (in this case 20 years ago), as the basis to make qualitative judgments about the quality of their soils. This positive relationship with net revenue therefore implies that, as the nutrient level of the soil 
is enhanced through the application of both organic and inorganic fertilizers, it would be reflected in higher land values.

Farm size determines the intensity of resource use by farmers. The positive influence of crop area on net revenue may be indicative of how farm management plays a crucial role in the circumstance of climate change. Benhin [34] observed that the size of cropland area is important, especially for rain-fed farmers, since a larger area enables them to spread their risk from adverse climatic effects and therefore reduces the net effects of the change.

Seed rate (quantity of seed required per area) of various field crops has a significant positive influence on farm net revenue. This implies that adherence to proper agronomic practices, such as planting the recommended kilograms of seed per unit area, could lead to optimum yield and increase farm revenue. This is an essential component in crop yield determination. The inclusion of this variable gave impressive results.

Our results also show a strong association of farmer demographic characteristics and farm net revenue from maize. Larger farming households are found to increase net revenue per hectare from both maize and sorghum. The positive relationship between household size and net revenue could imply that individuals are available in the households whose labor contribution enhances net revenue per hectare. This is similar to the findings of Benhin [34], who observed that household size may serve as a cheap source of labor for crop production, and this tends to raise crop production and farm income.

Extension service delivery is vital in crop production. Extension agents are expected to provide farmers with useful information on production technologies, efficient input combinations and market information, all aimed at enhancing farm productivity and incomes. Educated maize farmers obtain higher net revenues. Education tends to enhance the managerial ability of farmers, which is critical for efficient input combinations and improvements in productivity.

The econometric results and information on adaptation practices have several implications for agricultural production in Ghana, particularly Northern Ghana, where climatic conditions are generally more severe than the rest of the country. Historical data indicate a continuous decline in rainfall since the latter part of the 1970s and early 1980s. This downward trend in rainfall patterns still persists, as 20-year data show that temperatures in all zones in Ghana are rising, and rainfall has been decreasing and is becoming increasingly erratic [35]. The agricultural sector is one of most vulnerable sectors to climate change and variability in Ghana, as it mostly depends on natural rainfall. The trend for temperature over the period 2010 to 2050 indicates warming in all regions of Ghana, with the highest temperature in the three regions of the north. As a result, the sector is characterized by low productivity levels [36]. Crop production is more likely to be affected by high temperatures, especially with the limited moisture availability due to low amounts of rainfall. The current downward trend in crop yields would most likely continue because of the low level of soil fertility and other equally important environmental factors. The erratic rainfall pattern poses a threat to food security. Ghana's import of food commodities might increase, with the potential of further worsening the already weak local currency. Government revenue from the agricultural sector has dwindled over the past five years. To prevent a further decline in the sector's contribution to Ghana's GDP, government and key stakeholders will have to spend more on current adaptation measures (e.g., soil improvement/land management programs, irrigation and post-harvest losses) to climate change.

\section{Conclusions}

This study investigated the impacts of climate variables (rainfall and temperature) on maize and sorghum production and net revenues in selected districts across Northern Ghana. The study also identified farmers' perceptions of, and adaptation to climate change. The mean output of maize was $2327.38 \mathrm{~kg} / \mathrm{ha}$, with a corresponding net revenue of Ghф 2266.38 (US\$ 600.37), whereas mean output of sorghum was $1213.55 \mathrm{~kg} / \mathrm{ha}$, with net revenue of GHф 493.33 (US\$130.68). The estimates of the Ricardian regression models showed that precipitation and temperature impacted significantly 
on net revenue per hectare of maize and sorghum in Northern Ghana. Increasing precipitation (by $1 \mathrm{~mm}$ ), while decreasing temperature (by $1^{\circ} \mathrm{C}$ ), given the current levels, would affect net revenue, but differently across seasons and among various crops. The impact also varies in terms of magnitude and direction. Our results further show that soil quality as perceived by the farmers (loamy texture and fertility) and household characteristics/policy variables (education, number of extension contacts per season, farm size and seeding rate) contribute significantly to higher net revenue per hectare. Household characteristics are very important, as they may serve as good policy instruments for policymakers to explore as tools for controlling or taking advantage of climate effects. It is useful to see whether these variables explain crop net revenue. They could control or worsen the adverse impacts of climate change on crops. The findings of this study confirm the important link between climate and crop revenue and the need to take action to reinforce existing adaptation options and perhaps develop new ones.

The study identified about 40 specific adaptation strategies employed by farmers to reduce the effects of climate change on crop production. Some of these practices may have been in existence for a long time, but what made them useful strategies in relation to climate change has been the deliberate and increased use (compared to about 20 years ago) of these practices to minimize the effects of climate change. These practices were broadly grouped into crop adaptation, land management, farm operation, off-farm, livestock-related and other strategies. The study also found that there is a high perception of low soil fertility of farmlands across the study area, which some of the above-mentioned strategies are addressing.

Our findings in the econometric assessment, on adaptation practices and socio-economic factors, have implications for agricultural production in Ghana. Food security, government revenue and ecosystem services would probably be affected negatively by higher temperatures, erratic rainfall patterns, low soil fertility and various socio-economic factors. Given the current econometric analysis, the severe predicted impact of climate change in Northern Ghana would further affect agricultural land values. It is expected that the effective promotion of climate-related practices would reduce the harmful effects of rising temperature and declining rainfall on crop production.

The findings of this study have important policy implications that could enable farmers in Northern Ghana to improve their livelihoods. There is a need for government and other stakeholders in the agricultural sector to provide small-scale irrigation facilities or schemes to augment natural rainfall. This will reduce farmers' over-reliance on direct rainfall for maize and sorghum production. While this is expected to benefit the individual farmers, the government would need to ensure that this introduction is cost-effective and that it would not generate negative externalities (i.e., maladaptation), and perhaps a more appropriate approach may be needed to enable producers to change to different crop types.

There also is a need to build the capacities of smallholder farmers in Northern Ghana, so as to diversify their sources of livelihood. For example, engaging in non-farm income-generating activities, such as making handicrafts, petty trading and food processing, could reduce the risk they will face in the event of total crop failure as a result of unfavorable meteorological events. In addition, the Ghana Meteorological Agency and other agriculture-based institutions should provide farmers in Northern Ghana with practical and reliable information on seasonal rainfall and temperature patterns. Information on region-specific soil and plant health technologies should be generated by research institutes and disseminated in order to improve farmers' capacity to mitigate the negative impacts of climate change in Northern Ghana. Creating more awareness about the phenomenon of climate change and highlighting changes in rainfall and temperature are critical to facilitating the adoption of climate-related strategies. The capacities of change agents (such as self-motivated farmers and leaders of farmer-based organizations) in relation to the concept of climate change and the available adaptation strategies could be built in order to enhance widespread adoption. Agricultural extension services should be widely available to farmers in Northern Ghana in order to boost the adoption 
of climate-smart adaptation strategies. More agricultural extension agents could be employed and effective group dissemination techniques, such as farmer field fora, could be adopted.

Acknowledgments: The authors acknowledge the financial support provided by the CGIAR Research Program on Climate Change, Agriculture and Food Security (CCAFS) for the study. The immense editorial assistance provided by the Sustainability Office staff to bring the original manuscript to acceptable standard required by the journal is greatly appreciated and acknowledged.

Author Contributions: Anslem Bawayelaazaa Nyuor designed, collected, analyzed and wrote the paper. Emmanuel Donkor contributed much through his immense assistance offered in the data analysis and the shaping of the paper. Robert Aidoo edited and proofread this paper. He supervised the Master's thesis that resulted from the study. He therefore contributed to the conceptualization of the research problem, research design and discussion of results. Jesse B. Naab and Samuel Saaka Buah are the project coordinators of the CCAFS Project in Ghana. They made project funds available for this study and offered technical input in the methodology. Stephen K. Nutsugah is the Director of the Savanna Agricultural Research Institute (SARI) and signed the project contract between SARI and CCAFS. He also contributed to shaping the results and discussion sections. Jules Bayala and Robert Zougmoré were very instrumental in making sure that the main author undertook the project through a sponsorship from the CGIAR Research Program on Climate Change, Agriculture and Food Security (CCAFS). They reviewed and offered technical advice on the general framework of the article.

Conflicts of Interest: The authors declare no conflict of interest.

\section{References}

1. Ghana Statistical Service (GSS). Statistics for Development and Progress; National Accounts Statistics. Gross Domestic Product, 2014. Available online: http://www.statsghana.gov.gh/docfiles/GDP/GDP_2014.pdf (accessed on 4 January 2015).

2. Ministry of Food and Agriculture (MoFA). Agriculture in Ghana: Facts and Figures (2009); MoFA: Accra, Ghana, 2010.

3. Aryeetey, E.; McKay, A. Operationalizing Pro-Poor Growth: A Country Case Study on Ghana; A joint initiative of AFD, BMZ (GTZ, KfW Development Bank), DFID, and World Bank, 2004. Available online: http: //siteresources.worldbank.org/INTPGI/Resources/342674--1115051237044/oppgghana.pdf (accessed on 1 January 2014).

4. Breisinger, C.; Diao, X.; Thurlow, J.; Al-Hassan, R.M. Agriculture for Development in Ghana: New Opportunities and Challenges; IFPRI Discussion Paper 00784; International Food Policy Research Institute: Washington, DC, USA, 2008.

5. Dietz, T.; Millar, D.; Dittoh, S.; Obeng, F.; Ofori-Sarpong, E. Climate and livelihood change in North East Ghana. In Environment and Policy Series Volume 39: The Impact of Climate Change on Drylands, with a Focus on West Africa; Dietz, A.J., Ruben, R., Verhagen, A., Eds.; Kluwer Academic Publishers: Dordrecht, 2004; pp. 149-172.

6. Hesselberg, J.; Yaro, J.A. An assessment of the extent and causes of food insecurity in northern Ghana using a livelihood vulnerability framework. Geo. J. 2006, 67, 41-55. [CrossRef]

7. Sarpong, D.B.; Anyidoho, N.A. Climate Change and Agricultural Policy Processes in Ghana. 2012. Available online: http://www.hubrural.org/IMG/pdf/fac_working_paper_045_cc_and_agricultural_ policy_processes_in_ghana.pdf (accessed on 24 June 2014).

8. Adams, R.M. Global climate change and agriculture: An economic perspective. Am. J. Agric. Econ. 1989, 71, 1272-1279. [CrossRef]

9. Rosenzweig, C. Global climate change: Predictions and observations. Am. J. Agric. Econ. 1989, 71, $1265-1271$. [CrossRef]

10. Seo, S.N.; Mendelsohn, R.A. Ricardian Analysis of the Impact of Climate Change on Latin American Farms; World Bank Policy Research Series Working Paper 4163: Washington, DC, USA, 2007; Available online: http:/ / elibrary.worldbank.org/doi/abs/10.1596/1813-9450-4163 (accessed on 15 August 2015).

11. Seo, S.N.; Mendelsohn, R. An analysis of crop choice: Adapting to climate change in Latin American farms. Eco. Econ. 2008, 67, 109-116. [CrossRef]

12. Nkegbe, P.K.; Kuunibe, N. Climate Variability and Household Welfare in Northern Ghana. WIDER Working Paper 2014/027. 2014. Available online: https://www.wider.unu.edu/publication/climate-variability-andhousehold-welfare-northern-ghana (accessed on 20 August 2015). 
13. Gbetibouo, G.A.; Hassan, R.M. Measuring the economic impact of climate change on major South African field crops: A Ricardian approach. Glob. Planet. Chang. 2005, 47, 143-152. [CrossRef]

14. Kurukulasuriya, P.; Mendelsohn, R.A. Ricardian analysis of the impact of climate change on African cropland. Afr. J. Agr. Resour. Econ. 2006, 2, 1-23.

15. Kurukulasuriya, P.; Mendelsohn, R.; Hassan, R.; Benhin, J.; Deressa, T.; Diop, M.; Eid Helmy, M.; Fosu, K.Y.; Gbetibouo, G.; Jain, S.; et al. Will African agriculture survive climate change? World Bank Econ. Rev. 2006, 20, 367-388. [CrossRef]

16. Deressa, T.T. Measuring the Economic Impact of Climate Change on Ethiopian Agriculture: Ricardian approach. The World Bank Development Research Group Sustainable Rural and Urban Development Team: WPS4342, 2007. Available online: https://core.ac.uk/download/files/153/6616219.pdf (accessed on 15 October 2014).

17. Ngondjeb, Y.D. Innovation and development agriculture and climate change in Cameroon: An assessment of impacts and adaptation options. Afr. J. Sci. Tech. Innov. Dev. 2013, 5, 37-41.

18. Dasgupta, A.; Baschieri, A. Vulnerability to climate change in rural Ghana: Mainstreaming climate change in poverty-reduction strategies. J. Int. Dev. 2012, 22, 803-820. [CrossRef]

19. Jørgen, O.; Ngonidzashe, C.; Adiku, S. Climate change in Ghana: Impacts on agriculture and the policy implications. Ghana Policy J. Spec. Ed. Clim. Chang. 2013, 5, 40-57.

20. Issahaku, Z.A.; Maharjan, K.L. Crop substitution behavior among food crop farmers in Ghana: An efficient adaptation to climate change or costly stagnation in traditional agricultural production system? Agric. Food Econ. 2014. [CrossRef]

21. Rademacher-Schulz, C.; Schraven, B.; Mahama, E.S. Time matters: Shifting seasonal migration in Northern Ghana in response to rainfall variability and food insecurity. Clim. Dev. 2014, 6, 46-52. [CrossRef]

22. Escadafal, R.; Marques, M.J.; Stringer, L.C.; Akhtar-Schuster, M. Opening the door to policy relevant, interdisciplinary research on land degradation and development. Land Degrad. Dev. 2015, 26, 409-412. [CrossRef]

23. Mendelsohn, R.; Nardhaus, W.; Shaw, D. The impact of global warming on agriculture. A Ricardian analysis. Am. Econ. Rev. 1994, 84, 753-771.

24. Sanghi, A.; Mendelsohn, R.; Dinar, A. The climate sensitivity of Indian agriculture. In Measuring the Impact of Climate Change on Indian Agriculture; Dinar, A., Mendelsohn, R., Evenson, R., Parikh, J., Sanghi, A., Kumar, K., McKinsey, J., Eds.; Technical Paper No. 402; World Bank: Washington, DC, USA, 1998.

25. Polsky, C.; Esterling, W.E. Adaptation to climate variability and change in the US Great Plains: A multi-scale analysis of Ricardian climate sensitivities. Agric. Ecosyst. Environ. 2001, 85, 133-144. [CrossRef]

26. Kumar, K.; Parikh, S. Climate Change Impacts on Indian Agriculture: The Ricardian Approach. In Measuring the Impact of Climate Change on Indian Agriculture; Dinar, A., Mendelsohn, R., Evenson, R., Parikh, J., Sanghi, A., Kumar, K., McKinsey, J., Lonergan, S., Eds.; World Bank Technical Paper No. 402; World Bank: Washington, DC, USA, 1998.

27. Deschenes, O.; Greenstone, M. The economic impacts of climate change: Evidence from agricultural output and random fluctuations in weather. Am. Econ. Rev. 2007, 97, 354-385. [CrossRef]

28. Quiggin, J.; Horowitz, J. The impact of global warming on agriculture: A Ricardian analysis: A comment. Am. Econ. Rev. 1999, 89, 1044-1045. [CrossRef]

29. Reilly, J.N.; Hohmann, N.; Kane, S. Climate change and agricultural trade: Who benefits, who loses? Glob. Environ. Chang. 1994, 4, 24-36. [CrossRef]

30. Mendelsohn, R.; Dinar, A. Climate, water, and agriculture. Land Econ. 2003, 79, 328-341. [CrossRef]

31. Yu, Y.S.; Zou, S.; Whittemore, D. Non-parametric trend analysis of water quality data of rivers in Kansas. J. Hydrol. 1993, 150, 61-80. [CrossRef]

32. Gujarati, D.N. Basic Econometrics; McGraw Hill: New York, NY, USA, 2004.

33. Esteve, P.; Consuelo, V.O.; Blanco-Gutiérrez, I.; Downing, T.E. A hydro-economic model for the assessment of climate change impacts and adaptation in irrigated agriculture. Eco. Econ. 2015, 120, 49-58. [CrossRef]

34. Benhin, J.K.A. Climate Change and South. African Agriculture: Impacts and Adaptation Options; CEEPA Discussion Paper No. 21. Special Series on Climate Change and Agriculture in Africa, 2006. Available online: https:/ / www.weadapt.org/sites/weadapt.org/files/legacynew/knowledgebase/files / 5370f181a5657504721bd5c21csouth-african-agriculture.pdf (accessed on 15 April 2014). 
35. Cameron, C. Climate Change Financing and Aid Effectiveness: Ghana Case Study, 2011. Available online: http:/ / www.agulhas.co.uk (accessed on 20 December 2013).

36. World Bank. Economics of Adaptation to Climate Change. Ghana Country Study; World Bank: Washington, DC, USA, 2010.

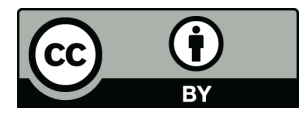

(C) 2016 by the authors; licensee MDPI, Basel, Switzerland. This article is an open access article distributed under the terms and conditions of the Creative Commons Attribution (CC-BY) license (http://creativecommons.org/licenses/by/4.0/). 